Jerzy Swędrowski ${ }^{1}$

Papieski Wydział Teologiczny św. Jana Chrzciciela w Warszawie

\title{
Głoszenie Ewangelii do osób zaangażowanych w działania społeczno-charytatywne
}

Wiele razy pojawia się postulat aktualizacji słowa Bożego; nie jest ono bowiem oderwane od życia i nie powinno być przekazywane jako dodatek do prywatnego praktykowania wiary. Dla głoszących i dla słuchaczy może pojawić się pokusa, aby słowa Bożego wysłuchać i odłożyć jako zabytek piśmiennictwa czy eksponat w muzeum. Wtedy można podziwiać estetykę słowa bez ingerencji tego słowa w konkret życia. Papież Benedykt XVI w adhortacji apostolskiej Verbum Domini zauważył:

Słowo Boże rzuca światło na ludzką egzystencję i mobilizuje sumienia do głębszego zastanowienia się nad własnym życiem, ponieważ całe dzieje ludzkości podlegają prawu Bożemu: „Gdy Syn Człowieczy zasiądzie w swojej chwale, a z Nim wszyscy aniołowie, wtedy zasiądzie na swoim tronie pełnym chwały. I zgromadzą się przed Nim wszystkie narody" (Mt 25, 31-32). W naszych czasach często traktujemy powierzchownie wartość przemijającej chwili obecnej, tak jakby była mało znacząca dla przyszłości (VD 99).

Słowa Pana Jezusa o czynnej miłości bliźniego, o uczynieniu dobra głodnemu, spragnionemu, nagiemu czy przebywającemu w więzieniu

1 Ksiądz dr Jerzy Swędrowski - kapłan diecezji łowickiej, jest proboszczem parafii św. Wawrzyńca, diakona i męczennika w Kutnie. Prowadzi wykłady z homiletyki w Wyższym Seminarium Duchownym w Łowiczu. E-mail: jswedrowski@diecezja.lowicz.pl. 
wyrywają nas z komfortowego rozważania idei, ale każą podejmować adekwatne do sytuacji czynności. Słowo Boże nie jest oderwane od konkretu życia; wręcz przeciwnie ono porządkuje to co jest realiami codzienności o pomaga budować dobre relacje. Papież Benedykt mówi:

Tak więc słowo Boże przypomina o konieczności naszego angażowania się w świecie i o naszej odpowiedzialności wobec Chrystusa, Pana dziejów. Głosząc Ewangelię, zachęcamy się wzajemnie do czynienia dobra i działania na rzecz sprawiedliwości, pojednania i pokoju (VD 99).

\section{Od słowa Bożego do czynnej miłości}

Słowo Boże nie jest teoretycznym przekazem zasad, ale staje się drogą życia poprzez jego osobowe przyjęcie. Cały wysiłek teologiczny i duszpasterski ma stawać się pomocą, aby ukazać w miarę integralny obraz człowieka. Wtedy osoba ludzka jawi się jako stworzona przez Boga, chciana przez Niego oraz do Niego podobna. Wówczas odkrywamy w człowieku jego godność, która niesie w sobie obecność człowieka doskonałego w Osobie Jezusa Chrystusa. Jednocześnie w ludzkim zaangażowaniu ujawnia się wewnętrzne zranienie, które swe źródło ma w grzechu pierworodnym ${ }^{2}$. Napięcie pomiędzy Bożym wybraniem a odrzuceniem daru pierwotnej szczęśliwości znajduje jedyną drogę w nawróceniu. Nawrócenie jest przywilejem ludzkiej wolności, bowiem jest uznaniem i przyjęciem mocy i władzy Boga objawionej w Jezusie Chrystusie 3 . Zatem każde nauczanie w Kościele ma wymiar chrystocentryczny, ten charakter jeszcze bardziej podkreśla jego powszechny zasięg. W Jezusie Chrystusie każdy ma szansę obiektywizować obraz Boga, siebie, bliźniego i świata.

Z pragnienia spotkania z Bogiem wypływają postawy, o których mówi prorok Izajasz: „...dzielić swój chleb z głodnym, wprowadzić w dom biednych tułaczy, nagiego, którego ujrzysz, przyodziać i nie odwrócić się od współziomków. Wtedy twoje światło zabłyśnie jak zorza i szybko rozkwitnie twe zdrowie. Sprawiedliwość twoja poprzedzać cię będzie,

2 Por. L. Balter, Jak mówićo człowieku, w: Prawdy wiary w przepowiadaniu, red. W. Przyczyna, Kraków 2002, s. 162.

3 Por. I. Jeż, Nawrócenie przywilejem ludzkiej wolności, Katowice 2001, s. 47. 
chwała Pańska iść będzie za tobą" (Iz 58, 7-8). Postawy, które rodzą się w sercu, mają wymiar społeczny, one są źródłem dobrze pojętego humanizmu. Humanizm bowiem afirmuje człowieka i widzi go jako ośrodek i szczyt wartości doczesnych, jak również jako podmiot autonomicznych działań. Z godności człowieka wypływa jego udział w dziełach życia kulturalnego i społecznego; to człowiek jest wezwany do wszechstronnego rozwoju i szeroko pojętej odpowiedzialności ${ }^{4}$. W perspektywie ewangelicznej człowiek podejmuje refleksję, z której wynika, że nie jest sam, że wokół niego są inni. Z tego odkrycia wypływa także świadomość, że nie jest samowystarczalny, jak również, że inni potrzebują pomocy, lecz także stają się darem.

Kościół u swoich początków twórczo odczytywał i realizował swoje powinności wobec potrzebujących, a jednocześnie formował tych, którzy mieli pójść z posługą charytatywną. Dzieje Apostolskie przynoszą informacje o powołaniu diakonów, którzy zostają skierowani do posługi:

„Nie jest rzeczą słuszną, abyśmy zaniedbywali słowo Boże, a obsługiwali stoły” powiedziało Dwunastu zwoławszy wszystkich uczniów. „Upatrzcież zatem, bracia, siedmiu mężów spośród siebie, cieszących się dobrą sławą, pełnych Ducha i mądrości! Im zlecimy to zadanie. My zaś oddamy się wyłącznie modlitwie i posłudze słowa" (Dz 6, 2-4).

Napięcie między posługą słowa i działalnością charytatywną wymaga twórczego współdziałania, aby nie doszło do grzechu zaniedbania, aby nie doszło od rozwodnienia osobistych i wspólnotowych powinności. W młodym Kościele weryfikowała się także szczerość intencji i postaw, o czym świadczy przykład Ananiasza i Safiry (zob. Dz 5, 1-11). Dążenie do wspólnoty wokół Osoby Jezusa Chrystusa i Jego słowa tak wtedy, jak również w perspektywie całego ziemskiego czasu staje się zasadą funkcjonowania wspólnoty wiary, która wzbogaca całą społeczność ludzką. Jeżeli Bóg jest ostatecznym źródłem godności człowieka, to jawi się konieczność integralnego i wszechstronnego rozwoju, który nie zamyka się w jednej osobie, ale staje się twórczym otwarciem na innych. Tą formą otwarcia staje się współcześnie wolontariat, który jawi się jako dobrowolne

4 Por. S. Kowalczyk, Humanizm, w: Encyklopedia katolicka, t. 6, red. J. Walkusz, Lublin 1993, k. 1311. 
i zorganizowane skierowanie ku potrzebującym. Wolontariat jest bezinteresownym podejmowaniem wspólnego wysiłku w zaspokojeniu najpilniejszych potrzeb ${ }^{5}$. Organizowanie się ludzi dobrej woli w strukturach własnych czy organizacji pozarządowych wnosi rys apostolstwa czynu. W jakimś sensie można go odnieść do realizacji kerygmatu na wzór pierwszych chrześcijan. Jest to kerygmat czynu; oznacza on propagowanie słowa Bożego oraz przykład postępowania zgodnego z głoszonym słowem. Posługa bliźniemu wpisuje się w praktyczne niesienie pomocy, co niejednokrotnie ociera się o heroizm ${ }^{6}$.

Papież Jan Paweł II postrzega wolontariat jako włączenie się w służbę ewangelii nadziei ${ }^{7}$. Z Ewangelii wypływają postawy, dzięki którym realizuje się bezinteresowny dar miłości. Chrześcijański wolontariat opiera się ma wartościach humanistycznych, co pozwala także dostrzec jego wymiar ekumeniczny i ponadreligijny. Jan Paweł II w adhortacji apostolskiej Ecclesia in Europa napisał:

Z samej swojej natury świadectwo miłości winno wyjść poza granice kościelnej
wspólnoty, by dotrzeć do każdego człowieka, tak aby miłość do wszystkich ludzi
stała się zaczynem prawdziwej solidarności w życiu społecznym. Kiedy Kościół
służy miłości, równocześnie umacnia „kulturę solidarności”, przyczyniając się
w ten sposób do utrwalenia powszechnych wartości ludzkiego współistnienia.
W tej perspektywie trzeba dowartościować autentyczny sens chrześcijańskiego
wolontariatu, który rodząc się z wiary i będąc nią stale ożywiany, musi stanowić
połączenie umiejętności zawodowych i autentycznej miłości, pozwalającej wszyst-
kim, którzy w niej uczestniczą, aby postawę zwykłej filantropii wynosili na wyżyny
miłości Chrystusa

Papież pokazuje źródło autentycznego życia społecznego, które rodzi się z wiary. On zachęca i pokazuje, aby zawsze i w każdym działaniu widzieć osobę człowieka.

Wiarygodność uczniów Chrystusa pomaga nawiązywać relacje, które staną się drogą do zaspokojenia godziwych i najbardziej elementarnych

5 Por. W. Przygoda, Wolontariat, w: Leksykon teologii pastoralnej, red. R. Kamiński, Lublin 2006, s. 908-911.

6 Por. F. Drączkowski, Kerygmat, w: Encyklopedia katolicka, t. 8, red. A. Bednarek i in., Lublin 2000, k. 1362.

7 Por. Jan Paweł II, adhort. apost. Ecclesia in Europa [dalej: EiE], 83.

8 EiE 85. 
potrzeb. Kościół w sposób szczególny daje wyraz trosce o ubogich i potrzebujących od swoich początków. Tę postawę zaleca sam Jezus Chrystus, zaś apostołowie pokazują ją jako praktyczny wyraz wiary (por. Dz 20, 35). Papież Jan Paweł II, zwracając się do społeczności, wiele razy zaznaczał, że wypowiada się w imieniu ubogich i słabych. Dotyczyło to braku elementarnych warunków godziwego życia, ale również braku wolności i możliwości rozwoju?

\section{Głoszenie Ewangelii wszystkim}

Posługa wolontariatu niesie w sobie znamiona ewangelizacji. Jezus Chrystus jest pierwszym w dziele ewangelizacji; On wybrał tych, których sam chciał, i im zaofiarował drogę wewnętrznej wolności. Oni dzięki Jego łasce mogli poradzić sobie z presją środowiska, z naciskami politycznymi i religijnymi; co więcej potrafili radzić sobie wobec trudności i braków ${ }^{10}$. Przełom XX i XXI wieku cechuje się szybkimi przemianami ekonomicznymi i społecznymi. Wspomniane przemiany wzmagają potrzebę wrażliwości chrześcijan. Dynamiczny rozwój gospodarczy, techniczny i kulturowy otwiera wielkie możliwości. Doświadczenie uczy, że z tych możliwości korzysta stosunkowo niewielka grupa osób. W tej sytuacji bardzo często jawnym i krzykliwym przeciwieństwem tego rozwoju stają się wykluczenie i bieda, które uwłaczają ludzkiej godności. Wolontariat jest poświęcaniem czasu i sił dla dobra społeczności i indywidualnym osobom, które są poza kręgiem rodzinnym. Jest to znak wewnętrznej wolności i znajdowania prawdziwie duchowych korzyści ${ }^{11}$.

Papież Jan Paweł II na zakończenie Wielkiego Jubileuszu roku 2000 wskazał na potrzebę czynienia Kościoła domem i szkołą komunii. Owa duchowość wynika z wierności Bożemu zamysłowi i jest odpowiedzią na najgłębsze oczekiwania świata. Papież pisze: „Co to oznacza

9 Por. J. Koral, Dobroczynność, w: Jan Paweł II. Encyklopedia nauczania społecznego, red. A. Zwoliński, Radom 2005, s. 119-121.

10 Por. Z. Kowalski, Kerygma, Marki 2015, s. 230-231.

11 Por. M. Puzewicz, Chrześcijański wolontariat, w: Głosić Ewangelię nadziei, red. P. Kurzela, A. Liskowacka, Katowice 2004, s. 266-267. 
w praktyce? Także tutaj można by bezpośrednio przejść na płaszczyznę działania, ale błędem byłoby ulec tej pokusie. Zanim przystąpimy do programowania konkretnych przedsięwzięć, należy krzewić duchowość komunii, podkreślając jej znaczenie, jako zasady wychowawczej wszędzie tam, gdzie kształtuje się człowiek i chrześcijanin"12. Współczesny świat przyzwyczaja człowieka do tanich wzruszeń, do pozornego humanizmu, który pozwala zachować bezpieczną odległość od drugiego człowieka, dlatego papież wskazuje na wypełnienie koniecznego warunku; zobaczenia w prawdzie drugiego człowieka: „Duchowość komunii to także zdolność dostrzegania w drugim człowieku przede wszystkim tego, co jest w nim pozytywne, a co należy przyjąć i cenić jako dar Boży: dar nie tylko dla brata, który bezpośrednio go otrzymał, ale także «dar dla mnie». Duchowość komunii to wreszcie umiejętność «czynienia miejsca» bratu, wzajemnego «noszenia brzemion» (por. Ga 6, 2) i odrzucania pokus egoizmu, które nieustannie nam zagrażają, rodząc rywalizację, bezwzględne dążenie do kariery, nieufność, zazdrość. Nie łudźmy się: bez takiej postawy duchowej na niewiele zdałyby się zewnętrzne narzędzia komunii. Stałyby się bezdusznymi mechanizmami, raczej pozorami komunii niż sposobami jej wyrażania i rozwijania" (NMI 43). Słowa Jana Pawła II oddają zasadę wspólnoty Kościoła, który nie zamyka się na innych; choć działa ponadkonfesyjnie, to znaczy służy także tym którzy są poza wspólnotą chrzcielną, ale przecież niosą w sobie obraz Boży.

W zwieńczeniu swojej posługi papież Jan Paweł II ogłosił Rok Eucharystii od października 2004 roku do października 2005 roku. Na ten czas napisał list, który stał się niejako jego testamentem. List Mane nobiscum Domine dotyka realnej obecności Jezusa Chrystusa w Eucharystii. Papież z Polski wskazał na postulat czynnej, realnej posługi, która wypływa z Eucharystii. Zwraca się do wierzących: „Dlaczego więc nie uczynić tego «Roku Eucharystii» czasem, kiedy wspólnoty diecezjalne i parafialne podejmowałyby szczególne zadania udzielania czynnej, braterskiej pomocy którejś z tak licznych grup ubogich całego świata. Myślę o dramacie głodu, który nęka setki milionów istot ludzkich, o chorobach będących biczem krajów rozwijających się, o samotności starszych,

\footnotetext{
12 Jan Paweł II, list Novo millennio ineunte [dalej: NMI], 3.
} 
o niedostatku bezrobotnych, o nieszczęściach imigrantów. Są to formy zła, które - choć w różnym stopniu - nękają również bogatsze regiony. Nie łudźmy się: za prawdziwych uczniów Chrystusa zostaniemy uznani, jeśli będziemy się wzajemnie miłować, a w szczególności jeżeli otoczymy troską potrzebujących (zob. J 13, 35; Mt 25, 31-46). To właśnie kryterium sprawdzenia autentyczności naszych celebracji liturgicznych"13. Jako potrzeba chwili jawi się lepsze zrozumienie powinności chrześcijańskich, które nie ograniczają się do wymiaru kultycznego. Świadectwo życia wartościami w społeczeństwie ma przyciągać i zachęcać do wchodzenia na drogę ewangelicznego stylu.

\section{Praktyka głoszenia, spotkanie słowa i czynu}

Dzielenie się dobrem z innymi jest znakiem odpowiedzialności i rozumienia wartości dobra wspólnego. Joseph Ratzinger - papież Benedykt XVI zauważył, że u początku trzeciego tysiąclecia nie można mówić, że jest ono bardziej chrześcijańskie. Problemem staje się wątpliwość, czy na gruncie religijnym poznawanie prawdy jest możliwe. Prowadzi to do konstatacji, że to, co jako prawda było dla człowieka zobowiązującą siłą i obietnicą, stało się jedynie kulturową formą wyrazu ogólnego uczucia religijnego ${ }^{14}$. Wobec traktowania religijności jedynie w wymiarze kulturowym nie można przechodzić obojętnie. Należy jednak szukać wspólnych punktów, które staną się perspektywą współpracy. Papież Franciszek w encyklice Laudato si’ pisze o zasadzie dobra wspólnego. Z tą zasadą wiąże się ludzka ekologia, która jawi się jako suma warunków pozwalających osobom i grupom społecznym osiągać coraz lepsze warunki życia. Dobro wspólne jest nakierowaniem na poszanowanie osoby ludzkiej, co pozwala na jej integralny rozwój. Z tym wiąże się dążenie do dobrobytu i bezpieczeństwa socjalnego osób i grup społecznych,

13 Jan Paweł II, List Mane nobiscum Domine, 28.

14 Por. J. Ratzinger, Wiara, prawda, tolerancja: chrześcijaństwo a religie świata, tłum. R. Zajączkowski, Kielce 2005, s. 130-132. 
a przede wszystkim rodziny. Takie działanie pozwala na wprowadzanie stabilności i ładu, co staje się promocją dobra wspólnego ${ }^{15}$.

W głoszeniu słowa Bożego jawi się potrzeba jedności prezbiterów i wszystkich członków Kościoła w służbie pokoju i sprawiedliwości. Ta jedność zakłada umiejętne oddzielenie bezpośredniego zaangażowania duchownych w układy polityczne i organizację życia społecznego i umożliwienie osobom świeckim realizacji ich inicjatyw ${ }^{16}$. Głoszenie słowa Bożego osobom zaangażowanym w działania społeczne wymaga szczególnego zwrócenia uwagi na wymiar wertykalny i horyzontalny, bowiem słowo i działanie $\mathrm{u}$ wolontariuszy wzajemnie się uzupełnia. Warto zwracać uwagę, jak bardzo służba bliźniemu aktualizuje słowo Boże. To słowo w liturgii nie wybrzmiewa jak zapis historyczny, ale jest zwrócone „tu i teraz”. Kreatywność kaznodziei jest szansą na pobudzanie kreatywności w działalności społecznej. Jeżeli wolontariusze chcą dać z siebie coś więcej niż jest tylko obowiązkiem, podobnie winien czynić kaznodzieja i wydobywać pogłębioną refleksję, która stanie się duchowym pokarmem ${ }^{17}$.

Posoborowe głoszenie kerygmatyczne wnosi powiew nowości i atrakcyjności. Jeżeli można mówić współcześnie o rozwoju wolontariatu, to jest to symptom autentycznego poszukiwania przez ludzi wartości wykraczających poza sferę materialną. Jest to jednocześnie sygnał zapotrzebowania na twórcze wsparcie tych, którzy decydują się dać coś ze swego życia innym. W samym Kościele niezwykle szeroką działalność podejmuje Caritas, ale to określenie nie dotyczy jedynie wymiaru jednej z instytucji. Ta posługa miłości i miłosierdzia rozlewa się znacznie szerzej. Angażujący się w wolontariat nie zawsze są wierzącymi, czy nie zawsze praktykują. Wobec wszystkich można jednak wychodzić z darem nowej ewangelizacji. Głoszącym słowo Boże potrzeba wielkiej delikatności i jednocześnie zapału. Nowa ewangelizacja ma pomóc nawiązywać żywą relację z Bogiem, ale ma także umacniać dotychczasową formację. Jest to propozycja porządkowania życiowych przestrzeni, gdzie w drugim

15 Por. Franciszek, enc. Laudato si', 157.

16 Por. Jan Paweł II, Posługa prezbiterów i kapłanów, Poznań 1998, s. 78.

17 Por. W. Pazera, Koncepcja homilii ewangelizacyjnej, Częstochowa 2002, s. 264. 
człowieku odnajdujemy Boga. Ta postawa nie ma nic z prozelityzmu, ale staje się radosną i otwartą propozycją spotkania ${ }^{18}$.

Podejmujący się działań w wolontariacie cechują się pasją działania; takiej pasji nie może być pozbawiony głosiciel słowa Bożego. Jego żywe zainteresowanie Pismem Świętym pomaga aktualizować Boży dar w konkrecie życia ${ }^{19}$. Pasja działania nie powinna być mylona z aktywizmem; może się czasem pojawić niesprawiedliwe oskarżenie o taką postawę. Niedocenianie bezinteresownych działań wobec bliźniego bądź oskarżenie o ukryte motywacje może doprowadzić do zniechęcenia lub zarzucenia podejmowanych działań. Głosiciel musi dobrze poznać mechanizmy komunikacji społecznej, ale nie może pozostać na poziomie sprawnego oglądu socjologicznego; on ma, zgodnie ze słowami św. Augustyna, karmić innych duchowym pokarmem, który jemu daje siłę życia ${ }^{20}$.

Zaangażowani w życie społeczne potrzebują znaków nadziei i pomocy. Zresztą niejednokrotnie bywa tak, że posługa pomocy innym ma swoje ukryte cele polityczne, ideologiczne czy biznesowe. Wobec wrażliwości ludzi prawdziwie bezinteresownych potrzeba, aby głoszący słowo Boże był świadkiem. Chodzi tutaj o świadectwo autentycznego życia chrześcijańskiego, ale także o świadectwo dobrze pojętego profesjonalizmu. Głoszenie słowa Bożego nie polega na powtórzeniu dobrze ułożonych fraz, ale na przekazywaniu nowego życia w Chrystusie, który nadaje sens życiu. To słowo Boże karmi utrudzonych i osłabionych; ono leczy poranionych i niedocenionych; ono także oczyszcza i porządkuje motywacje. Kaznodzieja może pokazać, co słowo Boże oznacza dla niego samego, a jego autentyzm może potwierdzić i wzmocnić świadectwo wspólnoty, z którą się dzieli tym słowem ${ }^{21}$.

Święty Jan Paweł II stał się dla Kościoła i świata na przełomie XX i XXI wieku heroldem bezinteresownej miłości. W bogactwie jego nauczania znajduje się homilia wygłoszona 9 czerwca 1979 roku w Krakowie na Błoniach. Przez analogię warto patrzeć na jego sposób zachęcania

\footnotetext{
Por. J. Dubiel, Jak mówić o nowej ewangelizacji, „Homo Dei” 2013 nr 2 (307), s. 124-125.

Por. L. Kuc, Krótki traktat o teologii komunikacji, Leszno, 1997, s. 241.

20 Por. M. Starowieyski, Karmię was tym, czym sam żyję, Warszawa 1984, s. 7.

21 Por. G. Siwek, Kaznodzieja jakoświadek, w: Sługa słowa, red. W. Przyczyna, Kraków 1997,
} s. 96-97. 
i pozyskiwania słuchaczy oraz wskazanie wiodących elementów. Papież mówił wtedy: ,...zanim stąd odejdę, proszę was, abyście całe to duchowe dziedzictwo, któremu na imię «Polska», raz jeszcze przyjęli z wiarą, nadzieją i miłością - taką, jaką zaszczepia w nas Chrystus na chrzcie świętym, abyście nigdy nie zwątpili i nie znużyli się, i nie zniechęcili; abyście nie podcinali sami tych korzeni, z których wyrastamy; [...] abyście mieli ufność nawet wobec każdej swojej słabości, abyście szukali zawsze duchowej mocy u Tego, u którego tyle pokoleń ojców naszych i matek ją znajdowało; abyście od Niego nigdy nie odstąpili; abyście nigdy nie utracili tej wolności ducha do której On «wyzwala» człowieka; abyście nigdy nie wzgardzili tą Miłością, która jest «największa», która się wyraziła przez Krzyż, a bez której życie ludzkie nie ma korzenia ani sensu"22. Warto ciągle badać i odkrywać sposoby dotarcia do słuchacza, a wartość podejmowanych dzieł ukazywać w perspektywie słowa Bożego.

22 Jan Paweł II, Dzieła zebrane, t. 9, Kraków 2008, s. 161. 


\section{Summary}

\section{Głoszenie Ewangelii do osób zaangażowanych w działania społeczno- -charytatywne}

Ewangelia jest Dobrą Nowiną dla każdego; jej zasięg wykracza poza granice konfesyjności, ale staje się źródłem sensu i siły wobec potrzebujących. Nie można podzielić się tym, czego się nie posiada, a zatem ugruntowanie na słowie Bożym oczyszcza i konkretyzuje postawy miłości wobec bliźniego. Niesienie pomocy innym nie dokonuje się w abstrakcji, ale ma u swojego celu niesienie chrześcijańskiej nadziei. Wszelkie formy wolontariatu i dobroczynności winny być ożywiane postawą wiary. W jej świetle można włączyć swoje umiejętności i środki materialne ku autentycznej miłości, która nie jest jedynie dystrybucją tego, co zbywa, ale otwieraniem dróg ku zaspokojeniu najpilniejszych potrzeb. Chrześcijański wolontariat niesie w sobie cechy wspólnotowe i nabiera charakteru apostolskiego. Słowo Jezusa Chrystusa, który „nie przyszedł, aby Mu służono, lecz żeby służyć i dać swoje życie na okup za wielu" (Mk 10,45) staje się motywacją ku odkrywaniu prawa miłości. To miłość Boża jest zasadą niesienia adekwatnej pomocy potrzebującym. Ta posługa staje się formą diakonii i pozwala na rozwinięcie nowej dynamiki misyjnej. Nie ma w niej nic z prozelityzmu, ale staje się ona prawdziwym zaczątkiem budowania wspólnoty osób. Zaangażowani w działania społeczno-charytatywne nie muszą popadać w aktywizm, ale karmiąc się słowem Bożym, znajdują siłę i radość w spotkaniu z bliźnimi. Oparcie zaangażowania społecznego na słowie Bożym i sakramentach buduje postawy tożsamości i zapobiega zniechęceniu. Formacja duchowa zaś pozwala budować trwałe fundamenty cywilizacji miłości i życia.

Słowa kluczowe: wolontariat, dobroczynność, kerygmat, wspólnota

\section{Proclamation of the Gospel to the People Involved in Social-Charitable Service}

The Gospel is the Good News addressed to everyone. Its message goes beyond confessional boundaries and becomes the source of sense and strength for those in any need. One cannot give what they do not have. Being firmly grounded in the Word of God people may experience it purifying power in the service to the neighbor. Helping other is not an abstraction but serving the needy has the purpose to give them Christian hope. Living faith is the center of all the voluntary services and charitable activities. Human creativity and material resources should be combined with our faith so that all is directed towards genuine love which sees the needy and shares not what is the surplus but meets their most urgent needs. Christian voluntary service carries in itself community traits and is apostolic by its nature. 


\section{Jerzy Swędrowski}

The Word of Jesus, who "For even the Son of man came not to be ministered unto, but to minister, and to give his life a ransom for many" (Mark 10,45) is the true motivation for discovering the law of love. God's love is rule how to help others.

Keywords: voluntary service, charitable activity, kerygma, community

\section{Bibliografia}

Franciszek, Adhortacja apostolska Laudato si'.

Jan Paweł II, Dzieła zebrane, t. 9, Kraków 2008.

Jan Paweł II, Adhortacja apostolska Ecclesia in Europa.

Jan Paweł II, Dekret Posługa prezbiterów i kapłanów, Poznań 1998.

Ratzinger J., Wiara, prawda, tolerancja: chrześcijaństwo a religie świata, tłum.

R. Zajączkowski, Kielce 2005.

Balter L., Jak mówić o człowieku, w: Prawdy wiary w przepowiadaniu, red. W. Przyczyna, Kraków 2002, s. 155-173

Dubiel J., Jak mówić o nowej ewangelizacji, „Homo Dei” 2013 nr 2 (307), s. 124-125.

Drączkowski F., Kerygmat, w: Encyklopedia katolicka, t. 8, red. A. Bednarek i in., Lublin 2000, k. 1360-1366.

Jeż I., Nawrócenie przywilejem ludzkiej wolności, Katowice 2001.

Koral J., Dobroczynność, w: Jan Paweł II. Encyklopedia nauczania społecznego, red. A. Zwoliński, Radom 2005, s. 119-121.

Kowalczyk S., Humanizm, w: Encyklopedia katolicka, t. 6, red. J. Walkusz, Lublin 1993, k. 1311-1314.

Kowalski Z., Kerygma, Marki 2015.

Kuc L., Krótki traktat o teologii komunikacji, Leszno 1997.

Pazera W., Koncepcja homilii ewangelizacyjnej, Częstochowa 2002.

Przygoda W., Wolontariat, w: Leksykon teologii pastoralnej, red. R. Kamiński, Lublin 2006, s. 907-911.

Puzewicz M., Chrześcijański wolontariat, w: Głosić Ewangelię nadziei, red. P. Kurzela, A. Liskowacka, Katowice 2004, s. 264-280.

Starowieyski M., Karmię was tym, czym sam żyję, Warszawa 1984.

Siwek G., Kaznodzieja jako świadek, w: Sługa słowa, red. W. Przyczyna, Kraków 1997, s. 83-108. 